\title{
ПРАВОВАЯ ХАРАКТЕРИСТИКА ДОГОВОРА ВОЗМЕЗДНОГО ОКАЗАНИЯ ОБРАЗОВАТЕЛЬНЫХ УСЛУГ В РОССИИ
}

\author{
(c) 2020 Малышкин Павел Викторович \\ кандидат юридических наук, доцент \\ Саранский кооперативный институт (филиал) \\ Российского университета кооперации, Россия, Саранск
}

(c) 2020 Усманова Елена Фанильевна

кандидат юридических наук, доцент

Мордовский государственный университет им. Н.П. Огарева, Россия, Саранск

E-mail: usmanowa_ef@rambler.ru

\section{(c) 2020 Шабаев Виктор Викторович}

кандидат исторических наук, доцент

Мордовский государственный педагогический институт им. М.Е. Евсевьева, Россия, Саранск

В статье раскрываются особенности договора возмездного оказания образовательных услуг. Отмечается, что специфика договора возмездного оказания образовательных услуг раскрывается через предмет данного договора, к которому относится процесс оказания образовательных услуг и его конечный результат: полученные знания, умения, навыки. Особенности отношений, вытекающих из договора возмездного оказания услуг, заключаются в тесном переплетении имущественных отношений и личных неимущественных, неразрывно связанных с личностью их носителя.

Ключевые слова: образование, обучение, образовательные услуги, гражданско-правовой договор, договор возмездного оказания услуг, обязательственное правоотношение.

Договор возмездного оказания образовательных услуг является разновидностью договора возмездного оказания услуг, его официального законодательного определения в российском гражданском законодательство не содержится.

В гражданско-правовой литературе же встречаются следующие формулировки данного понятия, например, Л.М. Волчанская определяет договор возмездного оказания образовательных услуг в системе высшего профессионального образования как «допускаемое законом письменное соглашение образовательного учреждения высшего профессионального образования, студента или слушателя и физического и (или) юридического лица (лиц) об установлении правоотношения, в которое вступают они с целью получения высшего профессионального образования» [1, с. 23].

Как видим, данное определение договора возмездного оказания образовательных услуг базируется на определении договора возмездного оказания услуг, но с учетом специфики образовательных услуг.

Необходимо выявить правовую природу договора возмездного оказания образовательных услуг в российском законодательстве, правовая природа какого-либо явления в юридической доктрине обычно определяется через родовую принадлежность к той или иной группе правовых явлений, исходя из их общего происхождения.

Касательно происхождения и отраслевой принадлежности договора возмездного оказания образовательных услуг, в отечественной науке гражданского права к настоящему времени не сложилось единства мнений российских ученых, специалистов в области российского гражданского права, существуют споры в отечественной доктрине относительно гражданскоправовой природы или ее отсутствия у договора возмездного оказания образовательных услуг.

В отечественной доктрине гражданского права можно выделить несколько подходов по вопросу о характере правовой природы рассматриваемого договор возмездного оказания образовательных услуг, к примеру, Е.А. Суханов, отрицая гражданско-правовой характер договора возмездного оказания услуг в сфере образования, приводит такие доводы, как невозможность применения к данному договору норм о защите 
прав потребителей и компенсации морального вреда; статус преподавателя не как научного работника, а только лишь как услугодателя; возможность применения норм административного права в виде, например, приказа ректора об отчислении обучающегося за нарушения правил внутреннего распорядка и дисциплины [6, с. 63].

Другой исследователь гражданского права В.И. Шкатулла относит сферу регулирования отношений, вытекающих из данного договора оказания возмездных образовательных услуг, к педагогическому или образовательному праву, указанное обстоятельство данный ученый связывает с отношениями субординации между образовательным учреждением и обучающимся, что регулируется, по его мнению, нормами административного права, но никак не гражданского [8, с. 8].

Подобных же взглядов на природу договора возмездного оказания образовательных услуг придерживается В.М. Сырых, которым приводятся такие доводы, как несоответствие требованиям гражданско-правового договора возмездного оказания услуг, а именно для стороны, получающей услуги образовательные услуги, на деле необходимо не только оплатить их (как предусмотрено в гражданско-правовой конструкции данного договора), но и активно участвовать в восприятии передаваемой информации в процессе образовательной деятельности [7, с. 72].

В качестве другого аргумента в пользу отсутствия гражданско-правовой природы данного договора возмездного оказания образовательных услуг выдвигается утверждение, что отношения субординации между обучающимся и лицом, предоставляющим образовательные услуги, и возможность применения дисциплинарных взысканий, не соответствуют принципу равенства, свойственному гражданскому праву.

Однако, при этом, В.М. Сырых говорит о наличии гражданско-правовой природы применительно к договору оказания возмездных услуг в рамках получения дополнительного образования, которое рассматривается им как обучение и в этом смысле соответствует положениям действующего гражданского законодательства, при чем данная позиция укрепилась после принятия второй части ГК Российской Федерации.

Напомним, что в рамках п. 2 ст. 779 ГК Российской Федерации, российским законодателем употребляется категория «услуги по обучению», а не «образовательные услуги», что в доктри- не российского гражданского права зачастую не рассматривается в качестве тождественных понятий, вместе с тем, «обучение» и «образование», - это взаимосвязанные правовые понятия и одно из них вытекает из другого.

Весьма оригинальна еще одна точка зрения на природу рассматриваемого договора возмездного оказания образовательных услуг, которая исходит из отрицания его гражданскоправового характера через признание трудовой (квазитрудовой) природы правоотношений, вытекающих из данного договора. Два элемента включаются в предмет договора на оказание возмездных образовательных услуг: а) образовательную деятельность по оказанию возмездных образовательных услуг и б) не овеществленный результат такой деятельности в виде навыков, знаний, умений.

Стороны договора об оказании возмездных образовательных услуг официально обозначены в «Правилах оказания платных образовательных услуг», утвержденных Правительством РФ в соответствии с федеральным законом об образовании № 273-Ф3:

Одна сторона данного договора - это заказчик, то есть это физическое и (или) юридическое лицо, имеющее намерение заказать либо заказывающее платные образовательные услуги для себя или иных лиц на основании договора;

Другая сторона данного договора - это исполнитель, то есть это организация, осуществляющая образовательную деятельность и предоставляющая платные образовательные услуги.

Помимо заказчика возмездных образовательных услуг и исполнителя возмездных образовательных услуг, как сторон данного договора в нем может фигурировать еще одна сторона данного договора, зачастую не совпадающая в одном лице с заказчиком,- это обучающийся, тот, кто непосредственно получает услуги по договору возмездного оказания образовательных услуг.

К числу основных обязанностей исполнителя возмездных образовательных услуг, как стороны договора, можно отнести обеспечение оказания платных образовательных услуг в полном объеме в соответствии с образовательными программами и условиями договора, а также предоставление достоверной информации об оказываемых образовательных услугах.

Обязанность о предоставлении образовательной организацией необходимой инфор- 
мации, в том числе, касающейся платных услуг, является важным условием соблюдения действующего законодательства об образовании РФ.

Обратимся к примеру из судебной правоприменительной практики по данному поводу, так 26 июня 2012 года Атяшевский районный суд Республики Мордовия вынес решение о необходимости устранения нарушения законодательства об образовании. [4] Суть дела состояла в следующем. На основании проведенной прокурорской проверки, прокурор Атяшевского района Республики Мордовия обратился с иском в интересах неопределённого круга лиц к МБОУ Атяшевского района РМ «Поселковская средняя школа № 2» о требовании устранить нарушения российского законодательства об образовании.

МБОУ «Поселковая средняя школа № 2» имеется сайт в сети «Интернет», но в нарушение требований федерального закона об образовании (ст. 32) на указанном сайте отсутствует информация о порядке оказания платных образовательных услуг. Суд признал требования истца обоснованными и вынес решение о понуждении ответчика исполнить указанные требования и устранить нарушения российского законодательства об образовании.

Одним из важнейших условий договора возмездного оказания образовательных услуг является стоимость услуг, хотелось бы остановиться на этом условии немного подробнее в связи с тем, что возмездность оказания образовательных услуг - это ключевой признак рассматриваемого договор, здесь интересен такой момент, как возможность или отсутствие такой возможности для изменения платы за образовательные услуги.

По этому поводу можно согласиться с мнением В.Э. Поляковой: «российским законодательством определен исчерпывающий перечень оснований для пересмотра стоимости обучения после заключения договора об возмездном оказании образовательных услуг» [2].

Исходя из общего правила, что изменение стоимости платных услуг после заключения договора возмездного оказания образовательных услуг не допускается, все же законодатель определяет некоторые исключения из этого правила: первое исключение из данного правила, связанно с возможностью увеличения стоимости образовательных услуг, исходит из роста инфляции, которое должно быть учтено в федеральном бюджете на очередной год (ч. 3 ст. 54 Закона об образовании); второе исключение из данного правила связано с возможностью уменьшения стоимости образовательных услуг по инициативе образовательной организации за счет покрытия разницы из собственных средств организации (ч. 5 ст. 54 Закона об образовании).

Основные моменты, связанные с исполнением договора возмездного оказания услуг, заключаются в выполнении всеми участниками данного договора возмездного оказания образовательных услуг своих обязательств по данному договору.

Для исполнителя договора возмездного оказания образовательных услуг - это совершение деятельности по оказанию услуг в сфере образования, для заказчика договора возмездного оказания образовательных услуг- это обязательство по оплате предоставленных образовательных услуг согласно данному договору, для обучающегося - это обязательство по усвоению передаваемой информации в процессе возмездного оказания образовательных услуг.

Нарушение ключевого условия об оплате услуг со стороны заказчика по договору возмездного оказания образовательных услуг дает основание его контрагенту - исполнителю договора возмездного оказания образовательных услуг либо приостановить встречное исполнение по данному договору, либо расторгнуть данный договор и потребовать возмещения причиненных убытков.

Проследим указанное положение на примере из судебной правоприменительной практики. ФГБОУ ВПО «Российский экономический университет имени Г.В. Плеханова» обратился в суд с иском к Ч. о взыскании задолженности по оплате образовательных услуг и неустойки за нарушение сроков оплаты, а также государственной пошлины за обращение в суд. Как следует из заявления, между истцом и ответчиком был заключен договор о предоставлении платных образовательных услуг на период обучения 3,5 года. Позже Ч. была отчислена из ВУЗа за академическую неуспеваемость и нарушение договора в части оплаты образовательных услуг.

Как установил мировой судья: заказчик обязан оплатить оказанные ему услуги в сроки и в порядке, которые указаны в договоре возмездного оказания услуг. В случае невозможности исполнения, возникшей по вине заказчика, услуги подлежат оплате в полном объеме, если иное не предусмотрено законом или договором 
возмездного оказания услуг. Заказчик вправе отказаться от исполнения договора при условии оплаты исполнителю фактически понесенных им расходов, исполнитель вправе отказаться от исполнения обязательств по договору лишь при условии полного возмещения заказчику убытков.

По своей правовой природе такая обязанность является мерой ответственности за нарушение обязательства [5].

В случае нарушения обязанности исполнителя по предоставлению образовательных услуг надлежащего уровня качества и расторжения договора по причине предоставления некачественных образовательных услуг, заказчику (обучающемуся) должна быть возращена сумма, внесенная по договору за не полученные услуги, за вычетом фактических расходов исполнителя, связанных с исполнением последним обязательств по заключенному договору.

Так, Ардатовский районный суд Республики Мордовия 22 апреля 2016 г. рассмотрел гражданское дело по иску Паниной И.П. к АНО «Образовательный центр изучения иностранных языков «Спик Ап». [3] Как следует из обстоятельств данного гражданского дела, 25.09.2015 г. истица Панина И.П. расторгла договор об оказании платных услуг в сфере образования в одностороннем порядке и потребовала возмещения суммы, оплаченной ею за образовательные услуги согласно договору.

Суд установил, что в соответствии с п. 1 ст. 782 ГК РФ, заказчик вправе отказаться от исполнения договора возмездного оказания услуг при условии оплаты исполнителю фактически понесенных им расходов, это условие также закреплено в Законе РФ от 7 февраля 1992 года № 2300-I «O защите прав потребителей»: потребитель вправе отказаться от исполнения договора о выполнении работ (оказании услуг) в любое время при условии оплаты исполнителю фактически понесенных им расходов, связанных с исполнением обязательств по данному договору.

Можно отметить, что российское законодательство гарантирует потребителю право на отказ от исполнения условий договора в любое время, однако связывает реализацию указанного права условием о фактических расходов исполнителя.

Относительно оснований, по которым договор возмездного оказания образовательных услуг прекращается, в ФЗ об образовании уста- новлен исчерпывающий их перечень, который может быть сгруппирован в три основные разновидности: 1) в связи с завершением обучения (получением образования) (ч. 1 ст. 61 Закона об образовании); 2) досрочное прекращение по инициативе той или иной стороны договора; 3) договор может быть прекращен в связи с форс-мажорными обстоятельствами, как не зависящими от воли Заказчика (Обучающегося) и Исполнителя (образовательной организации) (например, в случае ликвидации последней) (ч. 1 ст. 61 Закона об образовании).

Недопустимо включать в договор условия его прекращения, которые не предусмотрены законодательством.

В завершение хотелось бы высказать позицию по правовой природе рассматриваемого договора возмездного оказания образовательных услуг.

Специфика договора возмездного оказания образовательных услуг раскрывается через предмет данного договора, к которому относится оказание услуг в виде двух составляющих элементов: деятельности по предоставлению образовательных услуг и результату данной деятельности в не овеществленной форме - в виде знаний, умений, навыков.

Особенности отношений, вытекающих из договора возмездного оказания услуг, заключаются в тесном переплетении имущественных отношений (связанных с образовательной деятельностью, например, в виде проведения занятий, семинаров, лекций и т.д.) и личных неимущественных, неразрывно связанных с личностью их носителя (речь идет об отношениях по приобретению знаний, навыков, умений в процессе образовательной деятельности).

Еще одной стороной правовой природы рассматриваемого договора следует считать наличие административно-правовой составляющей, что выражается в необходимости получателя образовательных услуг подчиняться правилам внутреннего распорядка учебного заведения и требованиям его устава.

Обозначенные особенности позволяют нам прийти к выводу о сложном комплексном характере договора возмездного оказания услуг в сфере образования, что связано с сочетанием гражданско-правового и административноправового регулирования отношений, вытекающих из указанного договора, при преобладании гражданско-правовых начал. 


\section{Библиографический список}

1. Волчанская Л. М. Динамика договора возмездного оказания образовательных услуг // Юридическое образование и наука. 2002. № 2. С. 21-24.

2. Полякова В.Э. Возмездное оказание образовательных услуг 2015 [Электронный ресурс].- Доступ из СПС «Консультант Плюс».

3. Решение Ардатовского районного суда PM 22 апреля 2016 г.по делу 2-121/2016 [Электронный pecypc]. URL: https://rospravosudie.com/court-ardatovskij-rajonnyj-sud-respublika-mordoviya-s/act-518956138.

4. Решение Атяшевского районного суда РМ от 26 июня 2012 г. по делу № 2-249/2012 [Электронный ресурс].URL: https://rospravosudie.com/court-atyashevskij-rajonnyj-sud-respublika-mordoviya-s/act-106017434.

5. Решение Мирового судьи судебного участка Южского судебного района Ивановской области от 13 марта 2015 г. по делу № 2-154/2015 2015 [Электронный ресурс].- Доступ из СПС «Консультант Плюс».

6. Суханов Е. А. О правовом статусе образовательных учреждений // Вестник ВАС РФ. 2002. № 11. С. $62-73$.

7. Сырых В. М. О юридической природе образовательного договора с условием оплаты обучающимся стоимости обучения // Право и образование. 2002. № 4. С. 68-83.

8. Шкатулла В.И. Образовательное право. М.: Изд-во НОРМА, 2001. 688 с. 